\title{
Proposal of a PCM Underfloor Heating System Using a Web Construction Method
}

\author{
Sanghoon Baek and Jin Chul Park \\ School of Architecture and Building Science, Chung-Ang University, 221 Heuksuk 1-Dong, Dongjak-Ku, \\ Seoul 156-756, Republic of Korea
}

Correspondence should be addressed to Jin Chul Park; Jincpark@cau.ac.kr

Received 6 January 2017; Accepted 12 February 2017; Published 27 February 2017

Academic Editor: Geun Y. Yun

Copyright ( 2017 Sanghoon Baek and Jin Chul Park. This is an open access article distributed under the Creative Commons Attribution License, which permits unrestricted use, distribution, and reproduction in any medium, provided the original work is properly cited.

\begin{abstract}
Apartment buildings in Korea have adopted underfloor heating systems using web construction methods based on concrete and hot water systems. However, since such systems consume significant amounts of energy for heating owing to their low thermal storage performance, it is necessary to develop a new system that can minimize energy consumption by improving concrete thermal storage performance. This study proposes a phase-change material (PCM) underfloor heating system to reduce energy consumption in apartment buildings. An optimal design for a PCM underfloor heating system is proposed, and thermal storage performance of the proposed system is evaluated experimentally. The temperature range of the PCM for underfloor heating is also calculated considering the proposed design and comfortable heating conditions for domestic apartment buildings. Results indicate that a PCM underfloor heating system can be constructed in the following order: (1) a $210 \mathrm{~mm}$ concrete slab, (2) a $20 \mathrm{~mm}$ cushioning material, (3) $40 \mathrm{~mm}$ of mortar including a $10 \mathrm{~mm}$ PCM thermal storage container, and (4) $40 \mathrm{~mm}$ of finishing mortar including wire mesh and hot water pipes. The temperature range of the PCM used for underfloor heating in domestic apartment buildings is $32-45^{\circ} \mathrm{C}$. Experimental tests reveal that thermal storage performance of underfloor heating systems that apply $35,37,41$, and $44^{\circ} \mathrm{C}$ as representative PCM temperatures is superior to existing systems.
\end{abstract}

\section{Introduction}

As underfloor heating systems (UFHSs) use radiation from a floor surface for indoor heating, they can maintain indoor air temperature more comfortably than other types of heating systems [1-4].

In Korea, UFHSs have been widely used in residential buildings. Specifically, most apartment buildings, which account for approximately $65 \%$ of total residential buildings in Korea, adopt this type of heating system [5-10].

Unlike other countries that mainly use the dry construction method, most UFHSs applied to apartment buildings in Korea are constructed using the wet construction method.

System construction is completed by installing materials over a concrete slab in the following order: cushioning material, autoclaved lightweight concrete (ALC), wire mesh, hot water pipes, and finishing mortar. In addition, hot water, which is supplied by individual boilers or from the Korea
District Heating Corporation (KDHC), is used as the heat energy source [11]. Among these materials, ALC and finishing mortar are essential in determining heating energy consumption because they store or discharge the heat energy supplied by the hot water [12-17].

However, the poor thermal storage performance of ALC and finishing mortar necessitates a large supply of hot water and increases energy consumption. Moreover, when the hot water supply is interrupted, the underfloor surface temperature drops drastically. These are the disadvantages of UFHSs [18-20].

Therefore, a new UFHS with superior thermal storage performance should be designed to reduce heating energy consumption of apartment buildings in Korea.

Recently, a UFHS using a phase-change material (PCM) has been introduced as an alternative. This type of UFHS does not require an additional supply of heat energy but uses stored latent heat to maintain a constant temperature [21-41]. 
In the USA, China, Japan, and some European countries, such UFHSs using PCMs have already been actively studied and are being applied in both residential and nonresidential buildings [42-45].

However, most systems adopted in these countries use the dry construction method and electricity as a heat source $[25,43]$. For this reason, these systems are not suitable for Korean apartment buildings, which adopt the wet construction method and hot water as a heat source.

Consequently, it is necessary to design another type of PCM-based UFHS that can be applied to apartment buildings in Korea to reduce energy consumption. This study proposes a new PCM underfloor heating system (PUFHS) that uses the wet construction method and hot water.

For this, in Section 2, we analyze the current standard for underfloor heating of domestic apartment buildings and propose the optimal design of a PCM underfloor heating system that can improve the thermal storage performance of existing systems. Temperature ranges of PCMs that satisfy both indoor temperatures and floor surface temperature conditions for heating are also proposed. In Section 3, the experimental method and conditions for evaluating thermal storage performance for the proposed PCM underfloor heating system are explained, and Section 4 presents the analysis of the results obtained from the experimental tests.

\section{Design of a PCM Underfloor Heating System}

2.1. Standard for Underfloor Structure in Apartment Buildings. In Korea, the standard trend for underfloor structure of apartment buildings does not focus on energy consumption but on noise between floors, which has recently emerged as a social problem [46, 47]. However, every apartment building should conform to the "standard of structure for insulating floor impact sound between floors for noise prevention" by the Ministry of Land, Infrastructure and Transport (MOLIT).

The key points of this standard are as follows [11]:

(1) A heavy-weight floor impact sound of an underfloor structure shall be $50 \mathrm{~dB}$ or below.

(2) A lightweight floor impact sound of an underfloor structure shall be $58 \mathrm{~dB}$ or below.

(3) Otherwise, one of the standard underfloor structures suggested by MOLIT shall be adopted.

The underfloor structure of apartment buildings should conform to articles (1) and (2) of the abovementioned standard. Otherwise, as shown in Figure 1, one of the standard underfloor structures presented in article (3) should be adopted.

In Korea, most apartment buildings choose the first model of the standard underfloor structures in article (3) provided by MOLIT, as it is easy to construct and maintain and incurs low construction costs [49].

Almost all apartment buildings adopt the first standard underfloor structure in Figure 1; however, as mentioned in the introduction, this structure includes ALC and finishing mortar, which have very poor thermal storage performance
[18-20]. Therefore, in order to solve the problem of large energy consumption caused by underfloor heating, the thermal storage performance of ALC and finishing mortar must be improved. One of the most effective alternatives is to incorporate a PCM, which is a latent heat storage material, into the floor. The details of this solution are described in the following sections.

2.2. Concept of a PCM Underfloor Heating System. Figure 2 shows the design of the PUFHS proposed in this study to be applied in apartment buildings in Korea. Because of the MOLIT standard for floor thickness and noise between floors, the concrete slab and cushioning material shall be the same as before, whereas the ALC is replaced by mortar and PCM in order to enhance thermal storage performance.

In this structure, $15 \mathrm{~mm}$ of mortar, $10 \mathrm{~mm}$ of PCM, and $15 \mathrm{~mm}$ of mortar are sequentially installed over a concrete slab and cushioning material. Afterward, a wire mesh and $40 \mathrm{~mm}$ of finishing mortar including hot water pipes are installed over the cured mortar.

In this type of construction, the PCM can improve the thermal storage performance of both ALC and finishing mortar, and all stages of this process shall be the same as before except for the PCM installation, which also results in good constructability.

Although the MOLIT standard for light- and heavyweight floor impact sound requires testing and verification, no additional building material is necessary if the standard is satisfied. For this reason, the PUFHS proposed in this study is applicable to both existing and new apartment buildings as an alternative heating system in order to save energy.

2.3. Selection of PCMs for Underfloor Heating. The first step in constructing a PUFHS is to select a PCM that can satisfy the conditions of indoor temperature and underfloor surface temperature for apartment buildings in Korea.

Based on the initial conditions of indoor heating temperature $\left(T_{\text {in }}\right)$, underfloor surface temperature $\left(T_{\text {sur }}\right)$, and PCM temperature, the surface temperature of each underfloor layer can be calculated using (1), for which the mathematical model is shown in Figure 3 [50].

$$
\begin{aligned}
\dot{Q} & =\frac{T_{\mathrm{pcm}}-T_{\text {in }}}{R_{\text {total }}} \\
R_{\text {total }} & =\sum R_{\text {cond }}+R_{\text {sur }} \\
R_{\text {cond }} & =\frac{l}{k \cdot \mathrm{A}} \\
R_{\text {sur }} & =\frac{1}{\alpha \cdot \mathrm{A}} \\
T_{\text {mor }} & =T_{\text {pcm }}-\left(\dot{Q} \cdot R_{\text {cond,mor }}\right) \\
T_{\text {sur }} & =T_{\text {mor }}-\left(\dot{Q} \cdot R_{\text {cond,woo }}\right),
\end{aligned}
$$

where $\mathrm{A}\left(\mathrm{m}^{2}\right), k\left(\mathrm{~W} / \mathrm{m} \cdot{ }^{\circ} \mathrm{C}\right)$, and $l(\mathrm{~m})$ represent the surface area, thermal conductivity, and thickness, respectively. $\dot{Q}(\mathrm{~W})$ 


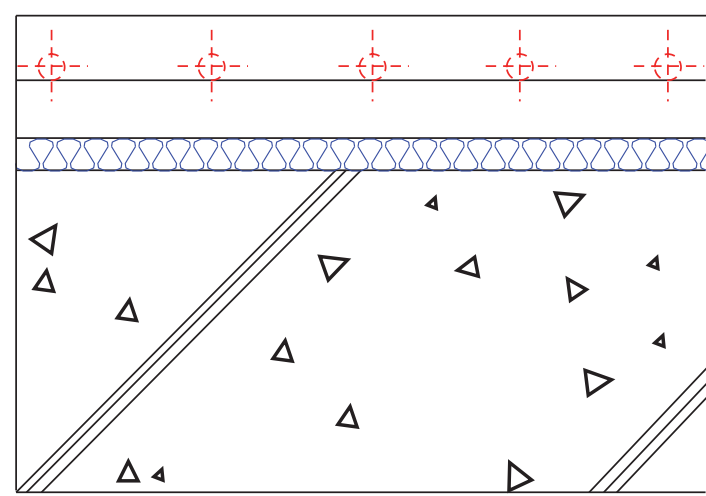

Standard underfloor construction-1

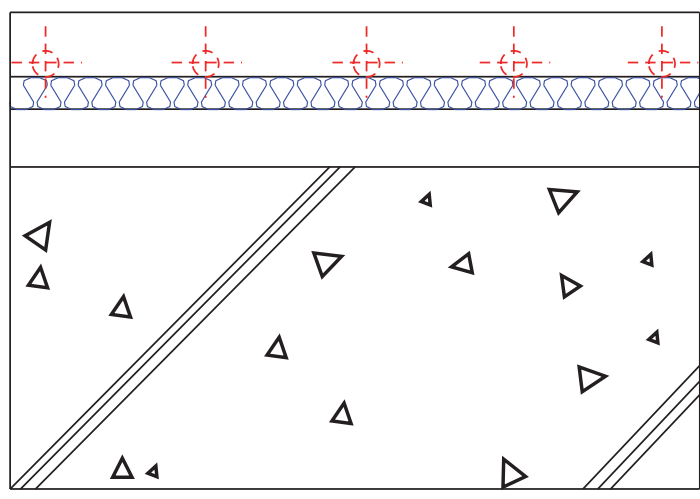

Standard underfloor construction-2

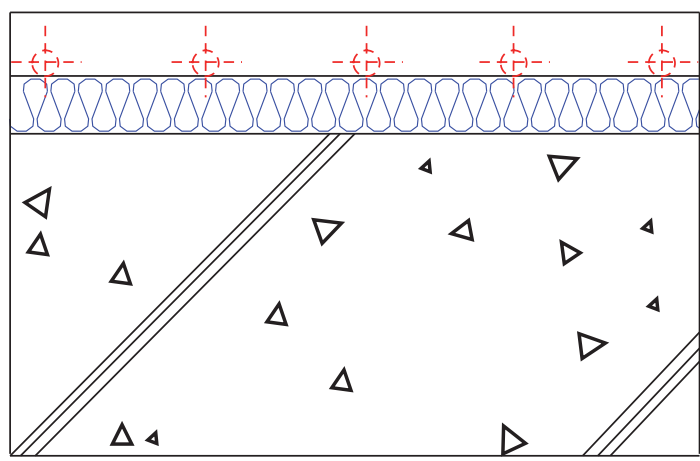

Standard underfloor construction-3
(1) Mortar (including hot water pipe)

\section{(2) ALC}

(3) Cushioning material

(4) Concrete slab

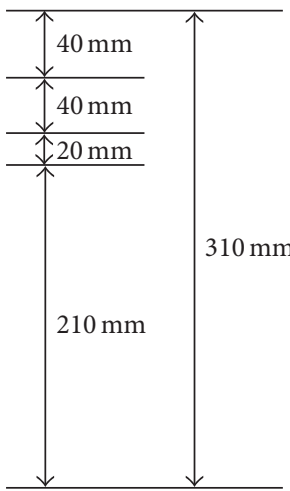

(1) Mortar (including hot water pipe)

(2) Cushioning material

(3) ALC

(4) Concrete slab

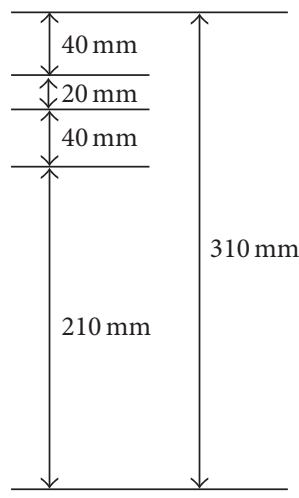

(1) Mortar (including hot water pipe)

(2) Cushioning material

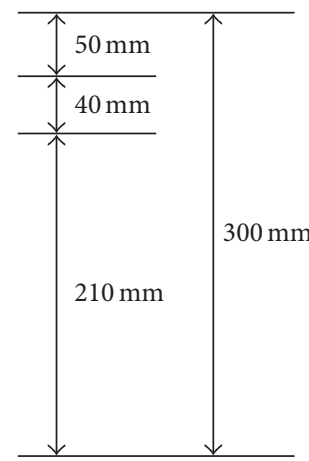

FIGURE 1: Standard underfloor structures proposed by MOLIT.

is the amount of heat transferred from the PCM to the heated space.

In addition, $R_{\text {total }}\left({ }^{\circ} \mathrm{C} / \mathrm{W}\right), R_{\text {cond }}\left({ }^{\circ} \mathrm{C} / \mathrm{W}\right)$, and $R_{\text {sur }}\left({ }^{\circ} \mathrm{C} / \mathrm{W}\right)$ are the total heat transfer resistance, thermal conductivity resistance of the phase-change material, and underfloor surface heat transfer resistance, respectively. $T_{\mathrm{pcm}}\left({ }^{\circ} \mathrm{C}\right), T_{\text {in }}\left({ }^{\circ} \mathrm{C}\right)$, $T_{\text {mor }}\left({ }^{\circ} \mathrm{C}\right)$, and $T_{\text {sur }}\left({ }^{\circ} \mathrm{C}\right)$ refer to the temperatures of the PCM, heat space, mortar, and underfloor surface, respectively. In addition, $\alpha\left(\mathrm{W} / \mathrm{m}^{2} \cdot{ }^{\circ} \mathrm{C}\right)$ is the total heat transfer coefficient of the underfloor surface.

As for initial conditions, the indoor heating temperature $T_{\text {in }}$ and the underfloor surface temperature $T_{\text {sur }}$ range from
22 to $26^{\circ} \mathrm{C}$ and from 28 to $30^{\circ} \mathrm{C}$, respectively, as proposed by recent studies conducted in Korea [51, 52].

Table 1 provides the temperatures for each layer calculated by applying these conditions.

When the indoor temperature $T_{\text {in }}$ was $22^{\circ} \mathrm{C}$, the temperature of the PCM satisfying the proposed underfloor surface temperature of $28-30^{\circ} \mathrm{C}$ was calculated to be in the range of $38-45^{\circ} \mathrm{C}$. When $T_{\text {in }}$ was $26^{\circ} \mathrm{C}$, the result of the calculation ranged from 32 to $39^{\circ} \mathrm{C}$.

As a result, the applicable temperature of the PCM that satisfies the conditions of indoor temperature and underfloor surface temperatures ranged from 32 to $45^{\circ} \mathrm{C}$. 

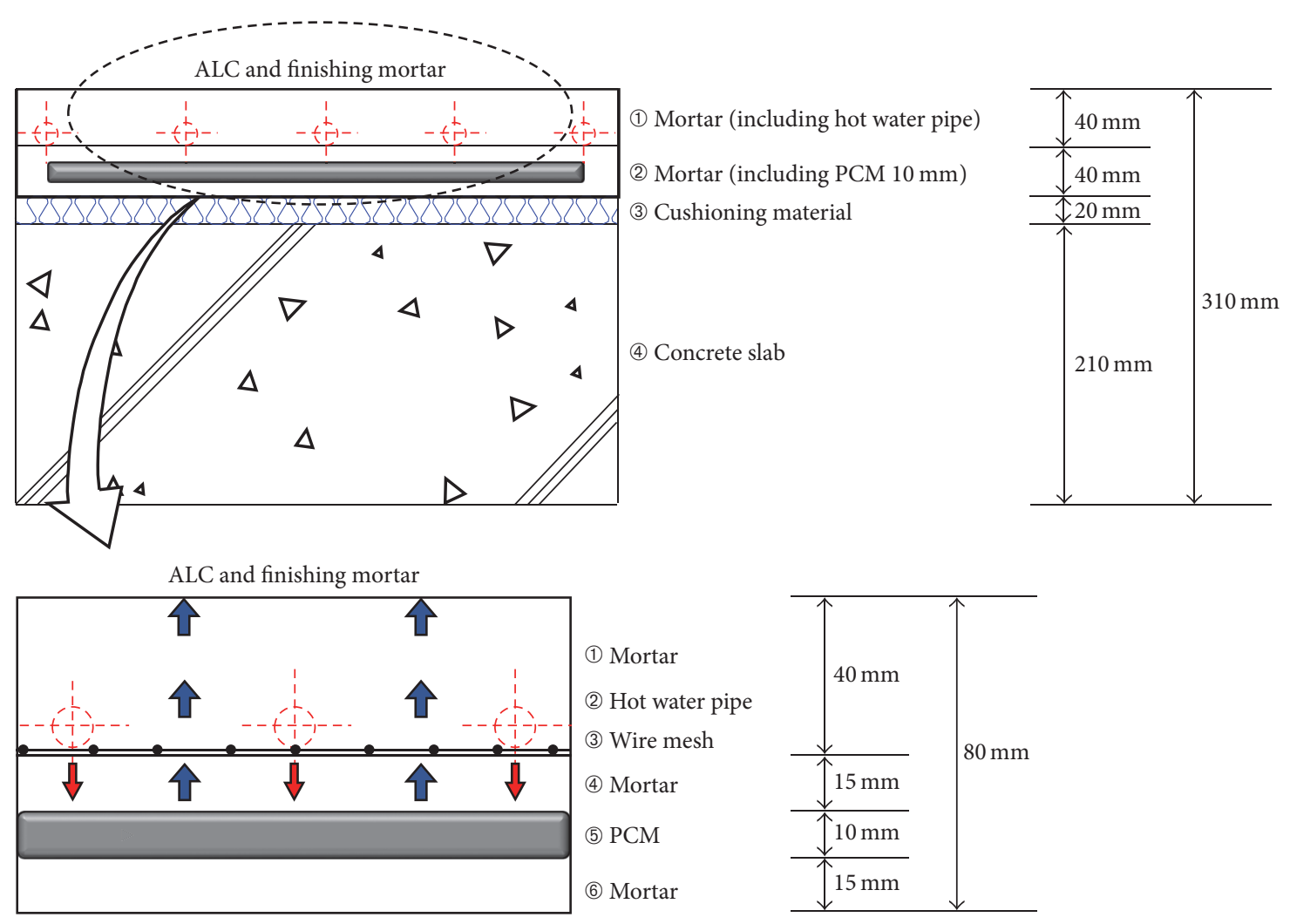

FIgURE 2: Design and characteristics of PCM underfloor heating system.

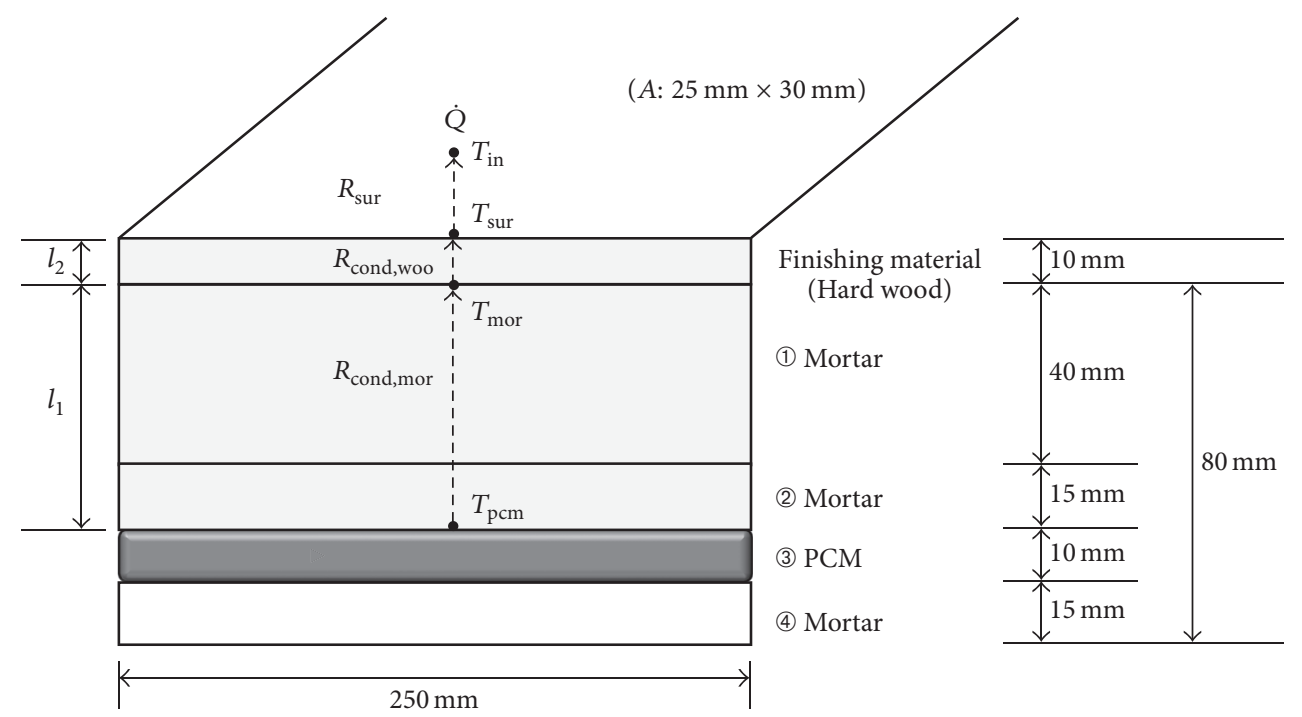

FIGURE 3: Mathematical model for producing optimal PCM for PCM underfloor heating system.

However, as PCMs are not produced in Korea and only some types of imported PCM are available, the types of PCM that satisfy the results above are extremely limited.

Therefore, considering the market conditions in Korea, the types of PCM applicable to underfloor heating have relevant temperatures of $35,37,41$, and $44^{\circ} \mathrm{C}$, and the thermal storage performance of a PUFHS using these four types of PCMs was evaluated by the experiments presented in the next section [48].

\section{Experimental Method}

3.1. Phase-Change Material. Based on results determined by the mathematical model above, PCMs with relevant temperatures of $35,37,41$, and $44^{\circ} \mathrm{C}$ can be used for the PUFHS, and the details of each PCM are shown in Table 2 [48].

3.2. PCM Thermal Storage Container. In order to integrate the selected PCM into the mortar, a container that can stably 
TABLE 1: Calculations of indoor underfloor surface and PCM temperatures.

\begin{tabular}{llll}
\hline $\begin{array}{l}T_{\mathrm{pcm}} \\
\left({ }^{\circ} \mathrm{C}\right)\end{array}$ & $\begin{array}{c}T_{\text {in }} \\
\left({ }^{\circ} \mathrm{C}\right)\end{array}$ & $\begin{array}{l}T_{\text {mor }} \\
\left({ }^{\circ} \mathrm{C}\right)\end{array}$ & $\begin{array}{l}T_{\text {sur }} \\
\left({ }^{\circ} \mathrm{C}\right)\end{array}$ \\
\hline 38.0 & 22.0 & 32.5 & 28.1 \\
39.0 & 22.0 & 33.2 & 28.5 \\
40.0 & 22.0 & 33.8 & 28.8 \\
41.0 & 22.0 & 34.5 & 29.2 \\
42.0 & 22.0 & 35.2 & 29.6 \\
43.0 & 22.0 & 35.8 & 30.0 \\
44.0 & 22.0 & 36.5 & 30.4 \\
45.0 & 22.0 & 37.1 & 30.7 \\
\hline 32.0 & 26.0 & 29.9 & 28.3 \\
33.0 & 26.0 & 30.6 & 28.7 \\
34.0 & 26.0 & 31.3 & 29.0 \\
35.0 & 26.0 & 31.9 & 29.4 \\
36.0 & 26.0 & 32.6 & 29.8 \\
37.0 & 26.0 & 33.2 & 30.2 \\
38.0 & 26.0 & 33.9 & 30.6 \\
39.0 & 26.0 & 34.6 & 30.9 \\
\hline
\end{tabular}

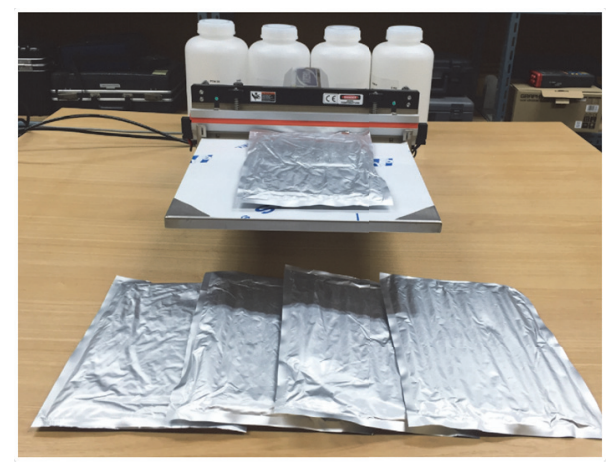

Figure 4: PTSCs embedded with PCM 35, 37, 41, and $44^{\circ}$ C.

perform thermal storage and discharge through a phase change is required.

For this purpose, a PCM thermal storage container (PTSC) was fabricated by incorporating the PCM into an aluminum container with high thermal conductivity as well as good corrosion resistance and durability within the mortar.

After $1 \mathrm{~kg}$ of the solidified $10 \mathrm{~mm}$ thick PCM was incorporated into an aluminum container $200 \mathrm{~mm}$ in width, $300 \mathrm{~mm}$ in depth, and $0.1 \mathrm{~mm}$ in thickness, air was removed from the aluminum container by a vacuum device, and the container was sealed by a hot wire at a temperature above $200^{\circ} \mathrm{C}$ [53].

Figure 4 shows the completed PTSCs embedded with PCMs with relevant temperatures of $35,37,41$, and $44^{\circ} \mathrm{C}$.

\subsection{Experimental Module of the PCM Underfloor Heating} System. As shown in Figure 5, a small underfloor module was fabricated to evaluate the thermal storage performance of a PUFHS that uses PTSC.
For the purpose of comparison, the existing UFHS module (number 1 in Figure 5) was made with a thickness of $80 \mathrm{~mm}$, which included $40 \mathrm{~mm}$ of ALC and $40 \mathrm{~mm}$ of finishing mortar. On the other hand, the module of the PUFHS proposed in this study (numbers 2-5 in Figure 5) was made with a total thickness of $80 \mathrm{~mm}$, which included (sequentially) $15 \mathrm{~mm}$ of mortar, $10 \mathrm{~mm}$ of PTSC, $15 \mathrm{~mm}$ of mortar, and $40 \mathrm{~mm}$ of finishing mortar.

Each module was fabricated using a wooden form (300 mm width $\times 400 \mathrm{~mm}$ depth $\times 200 \mathrm{~mm}$ height), and sufficiently solidified PCM and mortar were used for experimental evaluation.

3.4. Boundary Conditions. As the main focus of this study was to develop a PUFHS with a new underfloor design incorporating a suitable PCM, the process of incorporating a boiler and hot water pipes into the underfloor system was excluded from this study.

Consequently, an alternative heat energy supply system was needed; thus, we used a small constant-temperature chamber $(750 \mathrm{~mm}$ width $\times 250 \mathrm{~mm}$ depth $\times 650 \mathrm{~mm}$ height $)$.

As this chamber can control the supplied quantity of heat over a range of $0-70^{\circ} \mathrm{C}$, a sufficient quantity of heat can be supplied from the chamber to the underfloor system, similar to that when hot water is used as the heat energy source [54].

In addition, a monitoring system was used to collect temperature data during a set time period and to check the temperature change in real time [55]. The detailed configuration of the system is shown in Figure 6.

To compare thermal storage performance between the existing UFHS and the proposed PUFHS, temperature sensors were installed on the surfaces of the existing underfloor module and PUFHS module in order to monitor the variations of surface temperature with time.

In particular, both the existing and PUFHS modules were continuously heated at $46^{\circ} \mathrm{C}$, which exceeds the melting points of all PCMs, so that the PCM could store as much latent heat as possible.

After the underfloor modules were sufficiently heated, the heat energy supply from the constant-temperature chamber was stopped, and the decrease of surface temperature between the two modules was compared.

The results of the experiments conducted under these conditions are presented in the next section.

\section{Results and Analysis}

Figures 7-10 show the comparative results of temporal variation of surface temperatures between the existing underfloor module and the PUFHS module embedded with PCMs with relevant temperatures of $35,37,41$, and $44^{\circ} \mathrm{C}$, respectively, when the heat supply from the constant-temperature chamber was stopped.

Figure 7 shows the analysis of surface temperatures of the existing module and the PUFHS module embedded with a $35^{\circ} \mathrm{C}$ PCM. After the heat energy supply from the constanttemperature chamber was stopped, the surface temperatures of both modules decreased very similarly for a period of time; however, after approximately six hours, when the latent heat 
TABLE 2: Thermal characteristics of PCM in each temperature range [48].

\begin{tabular}{lccc}
\hline Product name & Chemical description & $\begin{array}{c}\text { Melting point } \\
\left({ }^{\circ} \mathrm{C}\right)\end{array}$ & $\begin{array}{c}\text { Heat storage capacity } \\
\mathrm{kJ} / \mathrm{kg}(\mathrm{Wh} / \mathrm{kg})\end{array}$ \\
\hline Celsius PCM 35 & Organic PCM & 35 & $208(57.6)$ \\
Celsius PCM 37 & Organic PCM & 37 & $200(55.4)$ \\
Celsius PCM 41 & Organic PCM & 41 & $200(55.4)$ \\
Celsius PCM 44 & Organic PCM & 44 & $230(63.7)$ \\
\hline
\end{tabular}

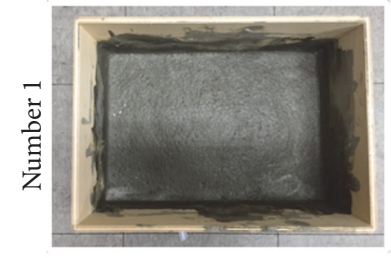

ALC $40 \mathrm{~mm}$

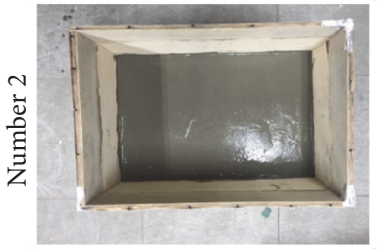

Mortar $15 \mathrm{~mm}$

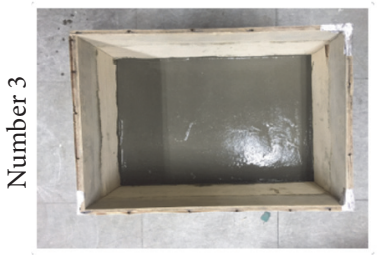

Mortar $15 \mathrm{~mm}$

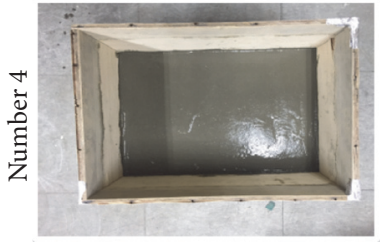

Mortar $15 \mathrm{~mm}$

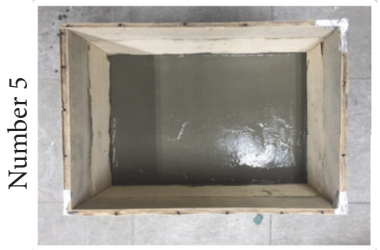

Mortar $15 \mathrm{~mm}$

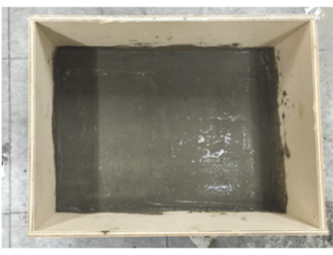

Mortar $40 \mathrm{~mm}$

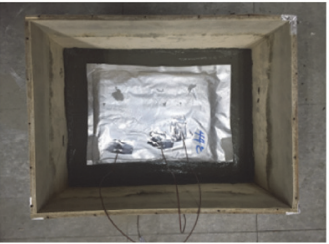

PTSC $35^{\circ} \mathrm{C} 10 \mathrm{~mm}$

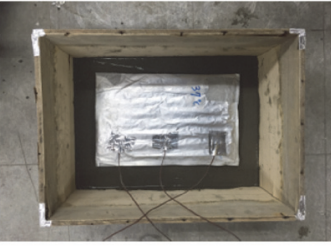

$\operatorname{PTSC} 37^{\circ} \mathrm{C} 10 \mathrm{~mm}$

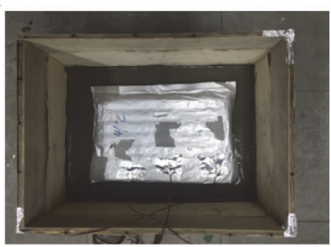

$\operatorname{PTSC} 41^{\circ} \mathrm{C} 10 \mathrm{~mm}$

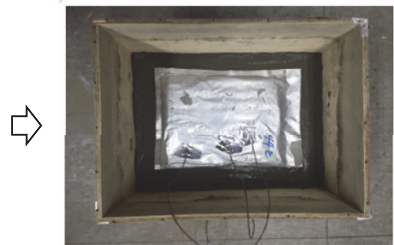

PTSC $44^{\circ} \mathrm{C} 10 \mathrm{~mm}$

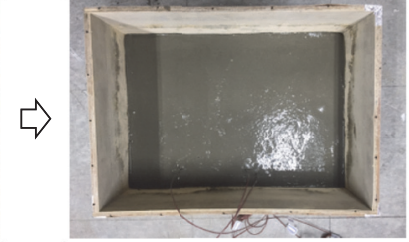

Mortar $55 \mathrm{~mm}$

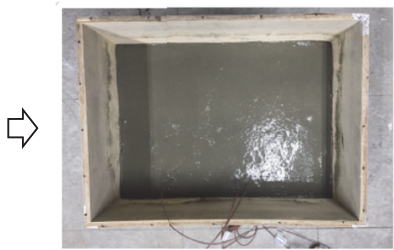

Mortar $55 \mathrm{~mm}$

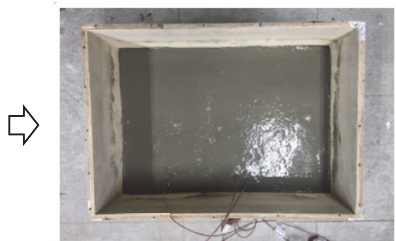

Mortar $55 \mathrm{~mm}$

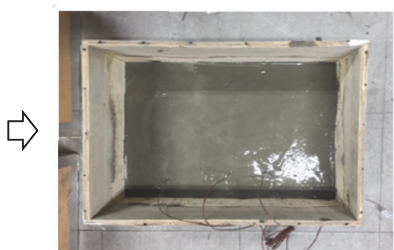

Mortar $55 \mathrm{~mm}$

FIGURE 5: Fabrication process of experimental modules for existing and PCM underfloor heating system.

of the PCM began to be discharged, the surface temperature of the PUFHS was maintained at approximately $35^{\circ} \mathrm{C}$ or decreased gradually. In particular, the surface temperature of the PUFHS did not decrease drastically, even after the latent heat of the PCM was exhausted. This was because the sensible heat stored in the PCM was discharged. The overall difference of surface temperatures between the existing module and the PUFHS module was calculated to be in the range of approximately $0.7-2.9^{\circ} \mathrm{C}$.

Figure 8 shows the analysis result of the surface temperatures of the existing module and the PUFHS module embedded with the $37^{\circ} \mathrm{C}$ PCM. Approximately four hours 


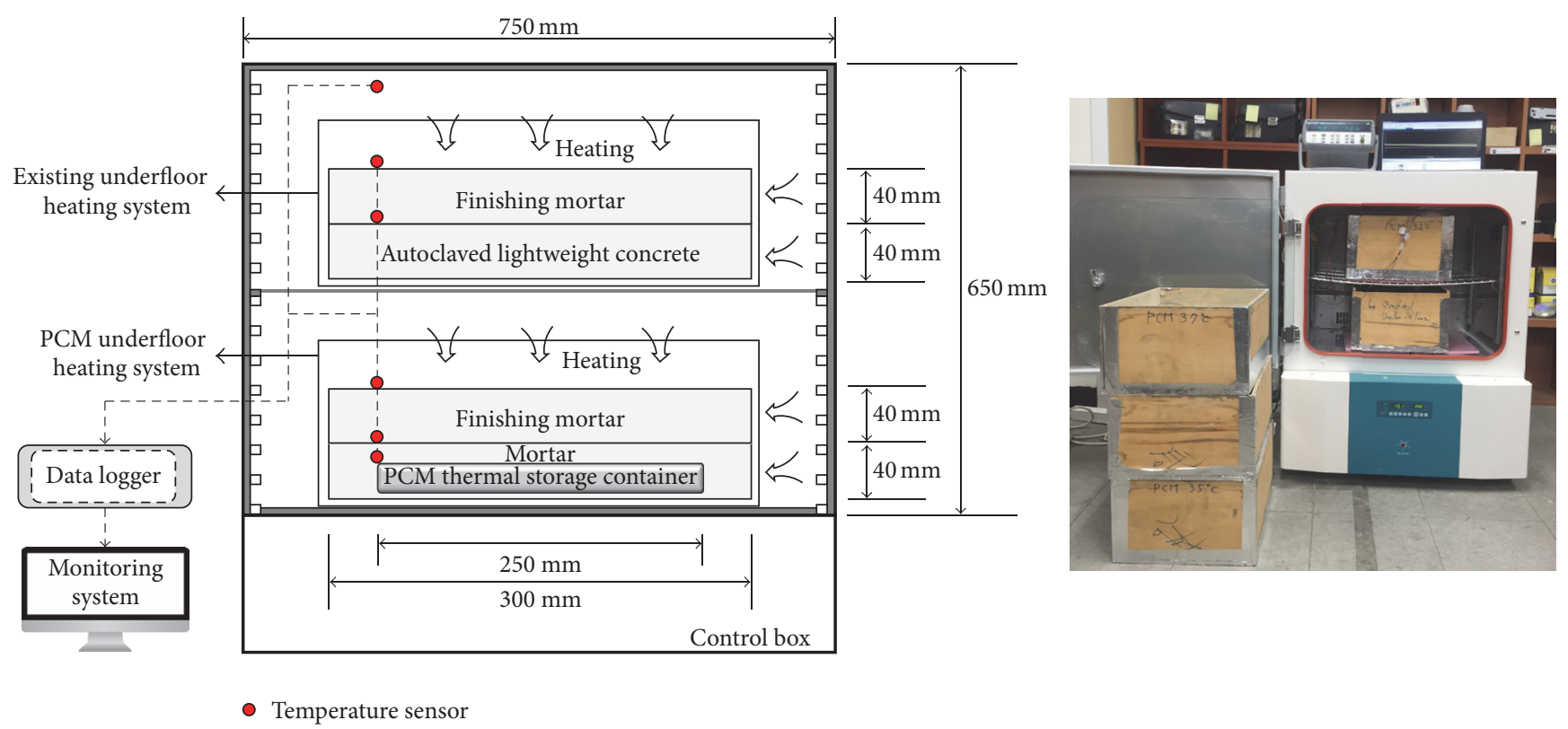

FIGURE 6: Construction of constant-temperature chamber and monitoring system.

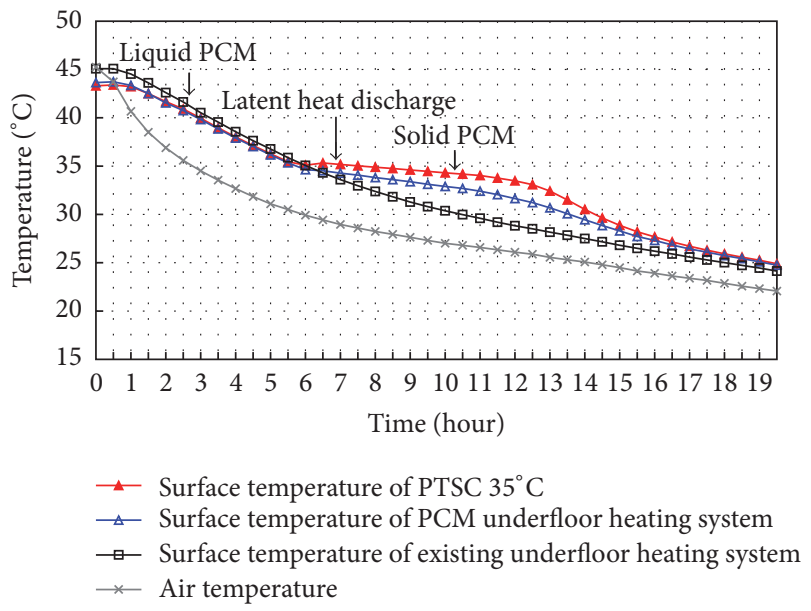

Figure 7: Surface temperatures of existing underfloor heating system and PUFHS with PTSC $35^{\circ} \mathrm{C}$.

after the heat energy supply was stopped, the latent heat discharge from the PCM started, resulting in approximately 1.3 to $4.4^{\circ} \mathrm{C}$ of surface temperature difference between the existing module and the PUFHS module. Although the same types of organic PCMs were used, the $37^{\circ} \mathrm{C}$ PCM discharged sensible heat after a short period of latent heat discharge. This was because the $37^{\circ} \mathrm{C} \mathrm{PCM}$ had less latent heat storage capacity than the $35^{\circ} \mathrm{C}$ PCM. In this case, a large amount of PCM would be required in order to maintain a constant surface temperature for a long period. Consequently, if this were applied to a real building, the initial investment cost would exceed those of other cases.

Figure 9 shows the analysis of surface temperatures of the existing module and the PUFHS module embedded with the $41^{\circ} \mathrm{C}$ PCM. Approximately four hours after the heat energy

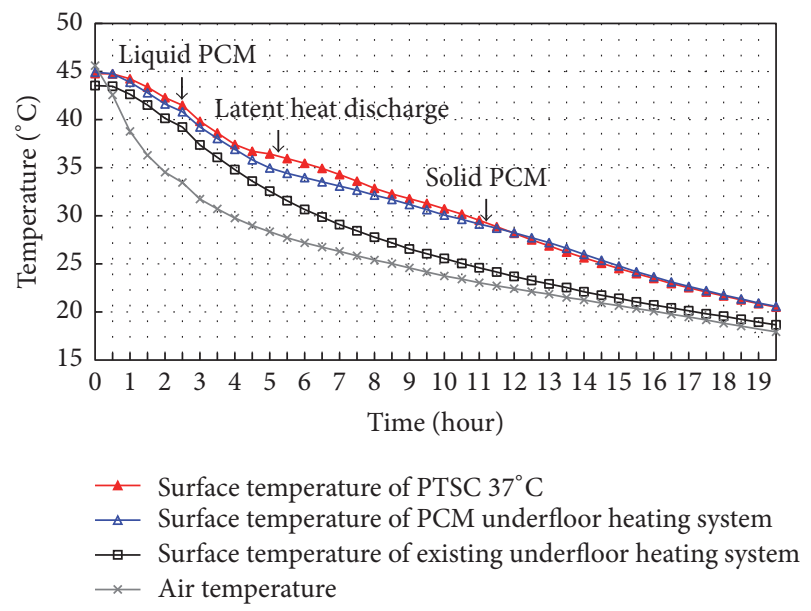

Figure 8: Surface temperatures of existing underfloor heating system and PUFHS with PTSC $37^{\circ} \mathrm{C}$.

supply was stopped, the latent heat discharge from the PCM started, resulting in approximately $1.7^{\circ} \mathrm{C}$ to $5.2^{\circ} \mathrm{C}$ of surface temperature difference between the existing module and the PUFHS module. This case produced the largest difference of surface temperature between the two modules in the latent heat section of the PCM. Furthermore, the duration of constant temperature caused by the latent heat was also the longest in this case.

Finally, Figure 10 shows the analysis of surface temperatures of the existing module and the PUFHS module embedded with the $44^{\circ} \mathrm{C}$ PCM. The difference of surface temperatures between the existing and PUFHS modules was approximately in the range of $0.7-4.1^{\circ} \mathrm{C}$. Approximately three hours after the heat energy supply was stopped, the latent heat was discharged. However, approximately one hour after 


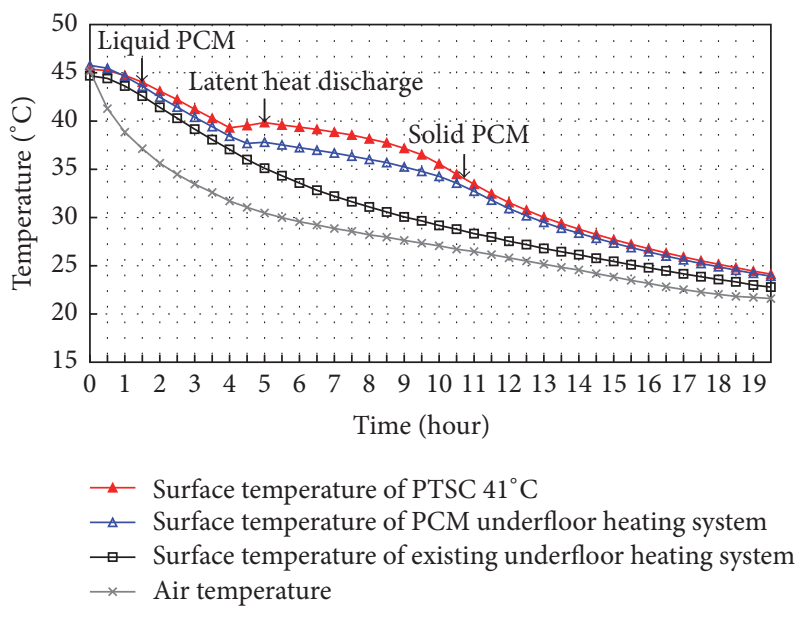

FIGURE 9: Surface temperatures of existing underfloor heating system and PUFHS with PTSC $41^{\circ} \mathrm{C}$.

the discharge, the surface temperature decreased drastically. We assume that this is because the $44^{\circ} \mathrm{C}$ PCM has a very low latent and sensible heat storage capacity; thus, it had the lowest performance for PUFHS among the candidate PCMs.

From the results of our experiment, we conclude that the $41^{\circ} \mathrm{C} \mathrm{PCM}$ is the most effective PCM that can be applied in a PUFHS for apartment buildings in Korea, as it has a large latent and sensible heat storage capacity and shows the largest difference of surface temperature compared with the existing module.

\section{Conclusion}

This study proposed a PUFHS for apartment buildings and evaluated its performance through experiments, of which the results are as follows:

(1) The structure of a PUFHS using the wet construction method and hot water to reduce heating energy in apartment housing is as follows:

(1) Concrete slab $(210 \mathrm{~mm})$

(2) Cushioning material $(20 \mathrm{~mm})$

(3) $\operatorname{Mortar}(15 \mathrm{~mm})$

(4) PTSC $(10 \mathrm{~mm})$

(5) Mortar (15 mm)

(6) Wire mesh

(7) Hot water pipes

(8) Finishing mortar (40 mm)

(2) For apartment buildings in Korea, the temperature conditions of indoor heating and the underfloor surface range from 28 to $30^{\circ} \mathrm{C}$ and from 32 to $45^{\circ} \mathrm{C}$, respectively. The temperature of the PCM satisfying these conditions is in the range of $32-45^{\circ} \mathrm{C}$.

(3) To integrate the underfloor structure and the PCM, an aluminum container with good thermal conductivity,

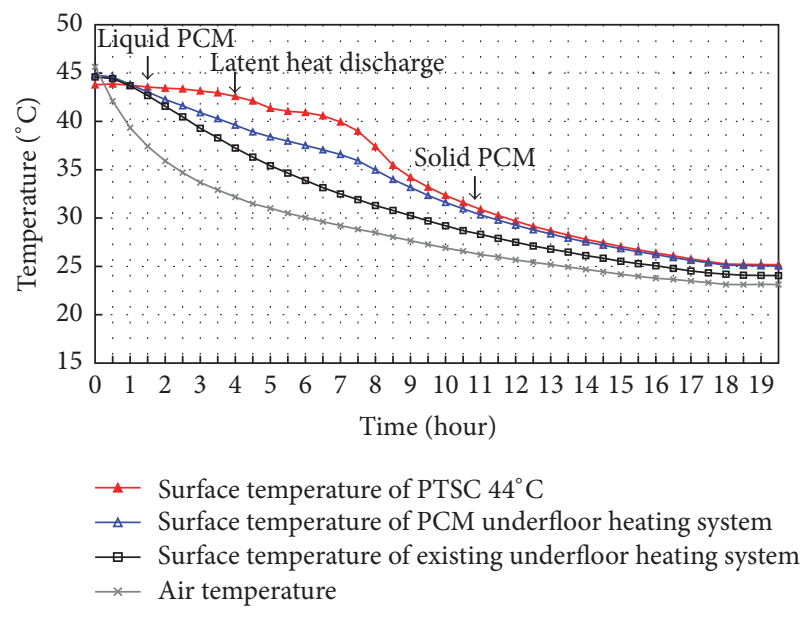

FIGURE 10: Surface temperatures of existing underfloor heating system and PUFHS with PTSC $44^{\circ} \mathrm{C}$.

corrosion resistance, and durability can be used as a PCM thermal storage container (PTSC).

(4) The types of PCM applicable to apartment buildings in Korea are PCMs with relevant temperatures of 35, 37,41 , and $44^{\circ} \mathrm{C}$, among which the $41^{\circ} \mathrm{C}$ PCM is the most suitable because it has the largest latent and sensible heat storage capacity and shows the largest difference of surface temperature compared with the existing underfloor module.

(5) The proposed PUFHS, which utilizes the wet construction method and hot water, can be adopted as a next-generation system to reduce heating energy consumption and greenhouse gas emissions in apartment buildings, which constitute approximately $65 \%$ of residential buildings in Korea.

\section{Competing Interests}

There are no competing interests to declare.

\section{Acknowledgments}

This research was supported by the Basic Science Research Program through the National Research Foundation of Korea (NRF) funded by the Ministry of Education (no. 2016R1D1A1B01015616).

\section{References}

[1] K.-N. Rhee and K. W. Kim, "A 50 year review of basic and applied research in radiant heating and cooling systems for the built environment," Building and Environment, vol. 91, pp. 166190, 2015.

[2] D. Wang, C. Wu, Y. Liu, P. Chen, and J. Liu, "Experimental study on the thermal performance of an enhanced-convection overhead radiant floor heating system," Energy and Buildings, vol. 135, pp. 233-243, 2017. 
[3] M. S. Shin, K. N. Rhee, S. R. Ryu, M. S. Yeo, and K. W. Kim, "Design of radiant floor heating panel in view of floor surface temperatures," Building and Environment, vol. 92, pp. 559-577, 2015.

[4] K. Rhee, B. W. Olesen, and K. W. Kim, "Ten questions about radiant heating and cooling systems," Building and Environment, vol. 112, pp. 367-381, 2017.

[5] S. M. Kim and H.-J. Kim, "Thermal stability and viscoelastic properties of MF/PVAc hybrid resins on the adhesion for engineered flooring in under heating system; ONDOL," Thermochimica Acta, vol. 444, no. 2, pp. 134-140, 2006.

[6] G.-S. Song, "Buttock responses to contact with finishing materials over the ONDOL floor heating system in Korea," Energy and Buildings, vol. 37, no. 1, pp. 65-75, 2005.

[7] J.-W. Choi, "Bed climate of Korean using ondol heating system," Journal of Thermal Biology, vol. 18, no. 5-6, pp. 399-403, 1993.

[8] S. K. Jeong and Y. U. Ban, "The spatial configurations in South Korean apartments built between 1972 and 2000," Habitat International, vol. 42, pp. 90-102, 2014.

[9] H. Seo, J. Sung, S.-D. Oh, H.-S. Oh, and H.-Y. Kwak, "Economic optimization of a cogeneration system for apartment houses in Korea," Energy and Buildings, vol. 40, no. 6, pp. 961-967, 2008.

[10] S.-S. Kim, D.-H. Kang, D.-H. Choi, M.-S. Yeo, and K.-W. Kim, "Comparison of strategies to improve indoor air quality at the pre-occupancy stage in new apartment buildings," Building and Environment, vol. 43, no. 3, pp. 320-328, 2008.

[11] Ministry of Land, Infrastructure and Transport Korea, Standard of Impact Sound Insulation Structure for Preventing Noise between Floors, 2015, http://www.lawnb.com/data/Focuslawdata/lawnbfocusB00039224457.pdf.

[12] J. Kim, J. Jeong, E. Hwang, and S. Shin, "Properties of foamed concrete according to types and concentrations of foam agent," Journal of the Korea Concrete Institute, vol. 24, no. 1, pp. 61-70, 2012.

[13] J. H. Choi, S. C. Shin, J. Y. Jeong, E. H. Hwang, and J. M. Kim, "Insulation properties of foamed concrete according to type and concentration of foaming agent," Korea Concrete Institute, vol. 5, pp. 189-190, 2012.

[14] T. B. Min and H. S. Lee, "A study on the properties of structure lightweight foamed concrete using the general aggregate and foaming agent," Architectural Institute of Korea, vol. 30, no. 1, pp. 225-226, 2010.

[15] I. Yang, K. Kim, and Y. Choi, "Effect of cementitious composite on the thermal and mechanical properties of fiber-reinforced mortars for thermal energy storage," Journal of the Korea Concrete Institute, vol. 28, no. 4, pp. 395-405, 2016.

[16] D. C. Park, H. Song, and J. J. Kim, "An experimental study on the thermal conductivity of PCM," Journal of the Architectural Institute of Korea, vol. 23, no. 10, pp. 107-114, 2007.

[17] K. S. Park, G. H. Cho, and D. C. Park, "A thermal characteristics study on the application method of activated carbon for a cement mortar finishing materials," The Korea Institute of Building Construction, vol. 11, no. 1, pp. 115-116, 2011.

[18] D. Bai, J. Kim, and H. Kim, "Experimental study on consumption of energy and heating efficiency in floor water heating system on using ondol panel of double metal rendering," Journal of the Korea Academia-Industrial cooperation Society, vol. 13, no. 12, pp. 6167-6175, 2012.

[19] C. H. Jeong, G. D. Lee, M. S. Yeo, and K. W. Kim, "Analysis and improvement strategy of the surface temperature distribution in a prefabricated floor heating panel through mock-up test,"
Journal of The Korean Society of Living Environmental System, vol. 20, no. 4, pp. 490-505, 2013.

[20] C. I. Jang, J. M. Kim, H. B. Kang, Y. N. Yoon, W. Y. Kim, and J. P. Won, "Evaluation of thermal effect for pp fiber reinforced lightweight aggregate polymer mortar," Proceedings of Korea Concrete Institute, pp. 215-216, 2009.

[21] S. A. Mohameda, F. A. Al-Sulaimana, N. I. Ibrahima et al., "A review on current status and challenges of inorganic phase change materials for thermal energy storage systems," Renewable and Sustainable Energy Reviews, vol. 70, pp. 1072-1089, 2017.

[22] H. Johra and P. Heiselberg, "Influence of internal thermal mass on the indoor thermal dynamics and integration of phase change materials in furniture for building energy storage: a review," Renewable and Sustainable Energy Reviews, vol. 69, pp. 19-32, 2017.

[23] S. Chandel and T. Agarwal, "Review of current state of research on energy storage, toxicity, health hazards and commercialization of phase changing materials," Renewable and Sustainable Energy Reviews, vol. 67, pp. 581-596, 2017.

[24] P. Lv, C. Liu, and Z. Rao, "Review on clay mineral-based formstable phase change materials: preparation, characterization and applications," Renewable and Sustainable Energy Reviews, vol. 68, pp. 707-726, 2017.

[25] K. Lin, Y. Zhang, X. Xu, H. Di, R. Yang, and P. Qin, "Modeling and simulation of under-floor electric heating system with shape-stabilized PCM plates," Building and Environment, vol. 39, no. 12, pp. 1427-1434, 2004.

[26] K. Lin, Y. Zhang, X. Xu, H. Di, R. Yang, and P. Qin, "Experimental study of under-floor electric heating system with shapestabilized PCM plates," Energy and Buildings, vol. 37, no. 3, pp. 215-220, 2005.

[27] Y. Zhang, J. Ding, X. Wang, R. Yang, and K. Lin, "Influence of additives on thermal conductivity of shape-stabilized phase change material," Solar Energy Materials and Solar Cells, vol. 90, no. 11, pp. 1692-1702, 2006.

[28] Y. P. Zhang, K. P. Lin, R. Yang, H. F. Di, and Y. Jiang, "Preparation, thermal performance and application of shape-stabilized PCM in energy efficient buildings," Energy and Buildings, vol. 38, no. 10, pp. 1262-1269, 2006.

[29] G. Zhou, Y. Zhang, X. Wang, K. Lin, and W. Xiao, "An assessment of mixed type PCM-gypsum and shape-stabilized PCM plates in a building for passive solar heating," Solar Energy, vol. 81, no. 11, pp. 1351-1360, 2007.

[30] K. Lin, Y. Zhang, H. Di, and R. Yang, "Study of an electrical heating system with ductless air supply and shape-stabilized PCM for thermal storage," Energy Conversion and Management, vol. 48, no. 7, pp. 2016-2024, 2007.

[31] G. Zhou, Y. Zhang, K. Lin, and W. Xiao, "Thermal analysis of a direct-gain room with shape-stabilized PCM plates," Renewable Energy, vol. 33, no. 6, pp. 1228-1236, 2008.

[32] W. Cheng, B. Xie, R. Zhang, Z. Xu, and Y. Xia, "Effect of thermal conductivities of shape stabilized PCM on under-floor heating system," Applied Energy, vol. 144, pp. 10-18, 2015.

[33] K. Huang, G. Feng, and J. Zhang, "Experimental and numerical study on phase change material floor in solar water heating system with a new design," Solar Energy, vol. 105, pp. 126-138, 2014.

[34] Y. Xia and X.-S. Zhang, "Experimental research on a doublelayer radiant floor system with phase change material under heating mode," Applied Thermal Engineering, vol. 96, pp. 600606, 2016. 
[35] G. Zhou and J. He, “Thermal performance of a radiant floor heating system with different heat storage materials and heating pipes," Applied Energy, vol. 138, pp. 648-660, 2015.

[36] Y. Zhang, C. Chen, H. Jiao et al., "Thermal performance of new hybrid solar energy-phase change storage-floor radiant heating system," Procedia Engineering, vol. 146, pp. 89-99, 2016.

[37] P. Llorach-Massana, J. Peña, J. Rieradevall, and J. I. Montero, "Analysis of the technical, environmental and economic potential of phase change materials (PCM) for root zone heating in Mediterranean greenhouses," Renewable Energy, vol. 103, pp. 570-581, 2017.

[38] I. Medved', A. Trník, and L. Vozár, "Modeling of heat capacity peaks and enthalpy jumps of phase-change materials used for thermal energy storage," International Journal of Heat and Mass Transfer, vol. 107, pp. 123-132, 2017.

[39] H. Ye, Z. Wang, and L. Wang, "Effects of PCM on power consumption and temperature control performance of a thermal control system subject to periodic ambient conditions," Applied Energy, vol. 190, pp. 213-221, 2017.

[40] S. J. Chang, Y. Kang, S. Wi, S. Jeong, and S. Kim, "Hygrothermal performance improvement of the Korean wood frame walls using macro-packed phase change materials (MPPCM)," Applied Thermal Engineering, vol. 114, pp. 457-465, 2017.

[41] N. P. Sharifi, A. A. Shaikh, and A. R. Sakulich, "Application of phase change materials in gypsum boards to meet building energy conservation goals," Energy and Buildings, vol. 138, pp. 455-467, 2017.

[42] Rubitherm, "Products page," 2016 http://www.rubitherm.eu/ en/productCategories.html.

[43] Mitsubishi, Floor heating system, 2016, http://www.mitsubishicable.co.jp/reinetsu/home/attakai/system/tikunetsu/index.html.

[44] PCM Thermal Solutions, Underfloor heating and residential/commercial heating uses of PCMs, 2016, http://www.pcmsolutions.com/underfloorheating.html.

[45] PCM product Ltd, "Environmental control applications," 2016 http://www.pcmproducts.net/Building_Temperature_Control .htm.

[46] S. G. Cha, "The management system and effect of floor noise at apartment houses," Korean Society for Noise and Vibration Engineering, vol. 10, pp. 693-697, 2014.

[47] S. G. Cha and H. J. Kim, "Effect of the trend of civil complaint and apartment price at management system of floor noise at houses," Korean Society for Noise and Vibration Engineering, vol. 2014, no. 10, pp. 704-709, 2014.

[48] Celsius Korea, Parafol Catalog, 2016, http://www.celsius.co .kr/phase_change_materials/download/data_sheet/Catalogue_ PARAFOL.pdf.

[49] D. H. Woon and H. G. Kim, "The economics value of residential heating systems in house price," Korean Energy Economic Review, vol. 7, no. 2, pp. 75-101, 2008.

[50] Y. A. Cengel, "Natural convection," in Introduction to Thermodynamics \& Heat Transfer, O. B. Kwon, E. P. Kim, T. G. Kim et al., Eds., pp. 217-260, Inter Vision Publishing Inc, Seoul, Republic of Korea, 2006.

[51] B. Y. Park, "A study on the thermal comfort zone in apartment house," Architectural Institute of Korea, vol. 5, no. 6, pp. 257-263, 1989.

[52] A. Tamura, C. S. Yoon, K. Fukai, and Y. S. Chung, "A comparative study on thermal responses of male and female in thermal environmental conditions in floor heating system," Architectural Institute of Korea, vol. 15, no. 5, pp. 127-134, 1999.
[53] Airzero Ltd, "Nozzle type vacuum sealer," 2016 http://www.airzero .co.kr/php/board.php?board=HtmlEN\&config=2\&category= 2\&indexorder $=2 \&$ command=body\&no $=39$.

[54] Jeio Tech, Heating and Cooling Chamber Catalog, 2016, http:// www.jeiotech.com/item.php?it_id=1361326243.

[55] Keysight Technologies, 34970A Data Acquisition/Data Logger Switch Unit, 2016, http://www.keysight.com/en/pd-1000001313\% 3Aepsg\%3Apro-pn-34970A/data-acquisition-data-logger-switchunit?nid=-33261.536881544\&cc=US\&lc=eng. 

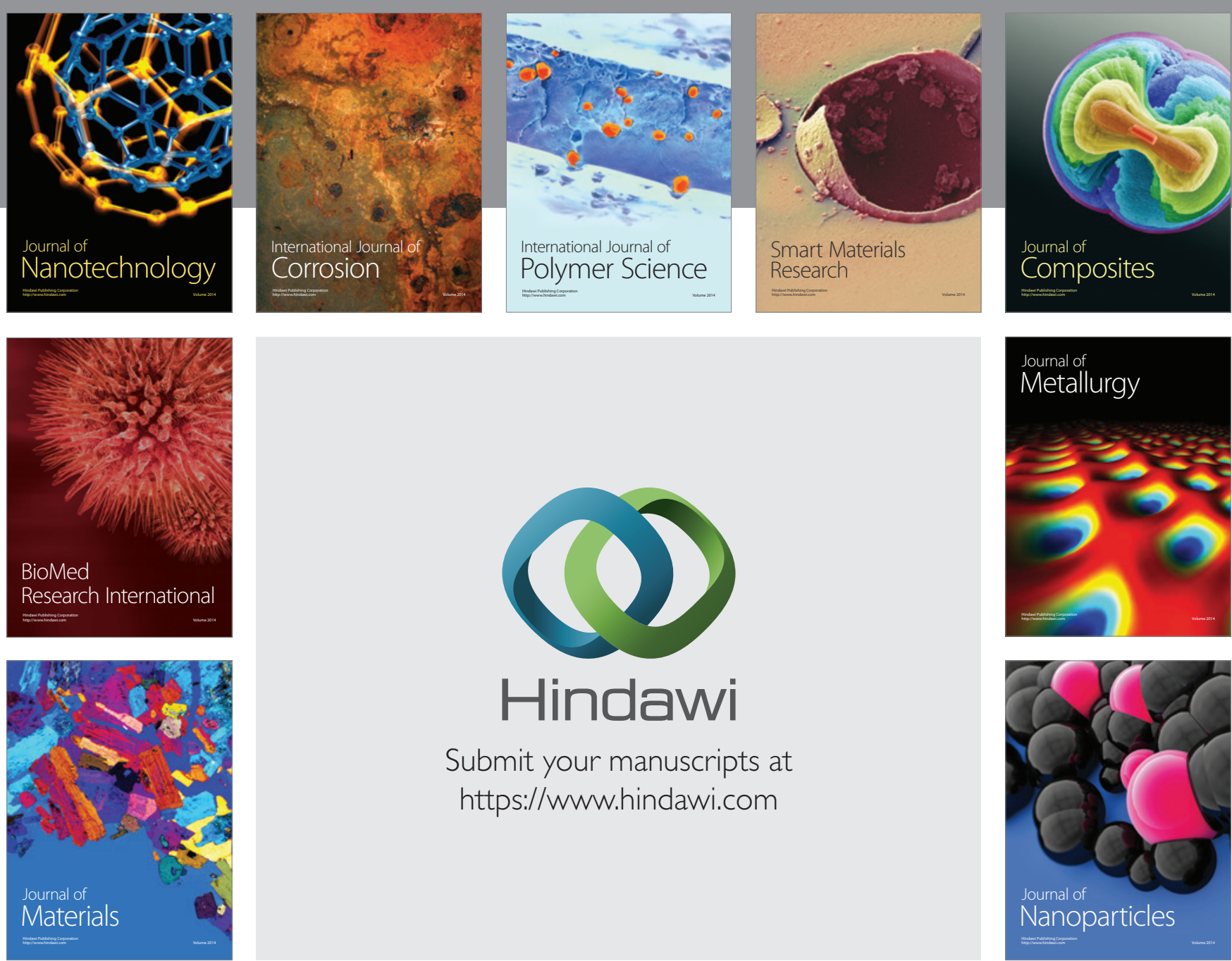

\section{Hindawi}

Submit your manuscripts at

https://www.hindawi.com

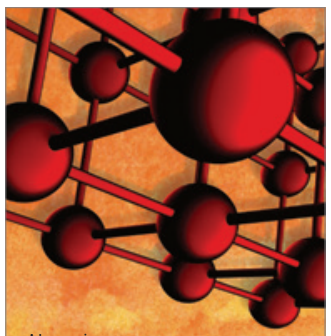

Materials Science and Engineering
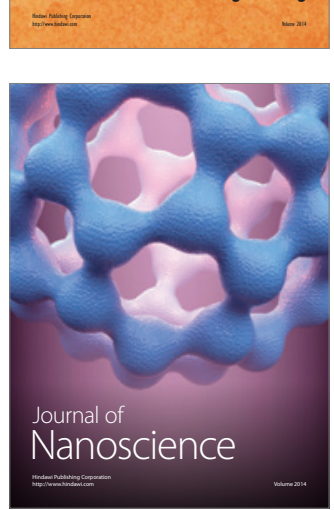
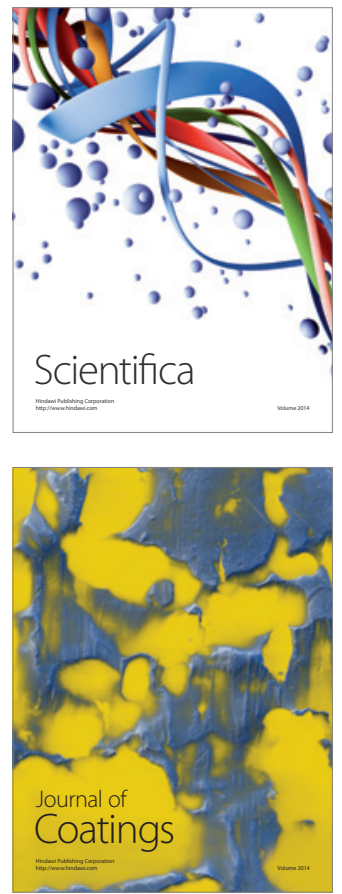
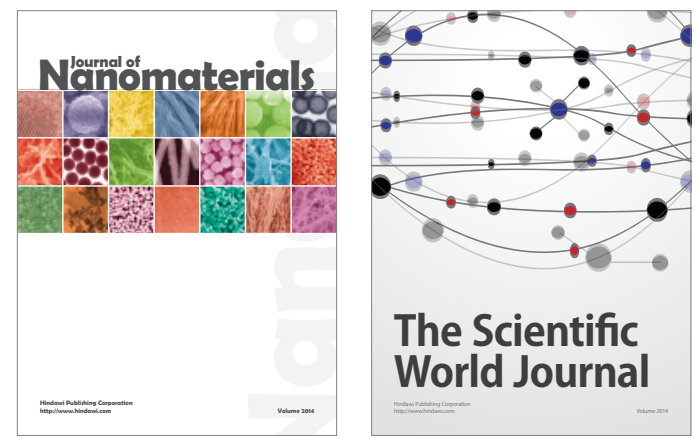

The Scientific World Journal
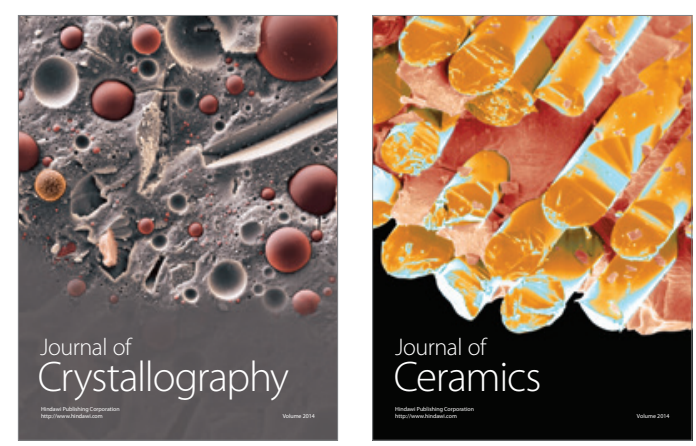
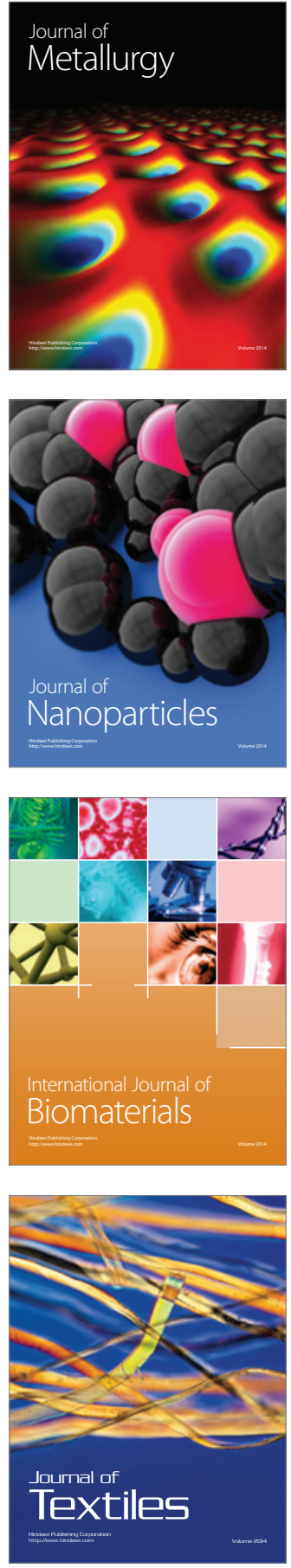